\title{
The Länder, the Bundesrat, and the legislative process in Germany and Europe
}

\section{The Federal Council, or Bundesrat}

\begin{abstract}
All federal states have some kind of second chamber that participates in the legislative process and represents the constituent parts of the whole, but Germany's second chamber is unique in the world's federal systems. ${ }^{1}$ It is unique in that it is a federal, not a Land, organ, in which the member states are represented by their governments (i.e., cabinets). This means it is an executive as well as a legislative body, and it means also that it is not a part of parliament, which is the Bundestag alone. Rather, it is a constitutional organ along with the Bundestag, the federal government, the Federal President, and the Federal Constitutional Court that makes it possible for the Länder, via their governments, to participate in the legislative process. Of course this means that the Bundesrat is also a product of the historical development of federalism in Germany and of the German second chamber. ${ }^{2}$
\end{abstract}

\section{History}

\section{The North German Federation and the Kaiserreich}

Germany did not become a nation-state until 1871 , following the FrancoPrussian War. From that time to the present, there have been five clearly delineated time periods and six - or possibly seven - political systems on German territory. These are the Kaiserreich, also known as Hohenzollern Reich or Bismarck Reich, of 187-1918; the Weimar Republic of 1918-33; Hitler's "Third Reich" of 1933-45; Allied occupation from 1945 to 1949; the German Democratic Republic (GDR) in the East from 1949 to 1989; 
and the Federal Republic of Germany (FRG) in the West from 1949 to the present. Some might argue that the unification of the latter two states in October 1990 by which the West German Federal Republic absorbed the former East Germany created yet another political system, but that is a questionable thesis that cannot be developed here. These different regimes range from monarchy to democracy to fascist dictatorship to military rule to communist dictatorship to Western democratic welfare state capitalism. No other Western country has gone through so many political changes in modern times.

In 1867 the North German Federation was formed under the guidance of the Prussian Prime Minister, Otto von Bismarck. It consisted of twenty-two states, all of which were monarchies, and three city-states, Hamburg, Bremen and Lübeck; not included were Austria or the south German states of Bavaria, Württemberg, and Baden. It represented a compromise between German tradition and the institutions of confederation on the one hand and the demands for some form of national union with a central government and the constitutionally guaranteed participation of the population on the other hand. It was, therefore, a compromise among monarchical, democratic, federal, and unitary principles within a constitutional framework that provided for a complicated division of powers and the de facto dominance of Prussia. Prussian dominance continued even after the founding of the Kaiserreich in 1871 that adopted with some revisions the North German Constitution as its own.

The Kaiserreich included the three south German states for a total of twenty-five states, ranging in size from Prussia, with three-fifths of the population and two-thirds of the area of the Reich, to tiny SchaumburgLippe with 32,000 inhabitants. Again, three of the states were "free" citystates and all of the twenty-two territorial states were monarchies. ${ }^{3}$ There were two chambers in the Reich, the popularly elected Reichstag and the Bundesrat which represented the states. Like the old Bundestag of the German Confederation, the Bundesrat was comprised of members who were rather like ambassadors sent by the state governments and instructed by them on how to vote. Therefore, in contrast to the Staatenhaus proposed by the Frankfurt Assembly of 1848-49, which was to be a part of parliament with members at least legally free to vote their consciences, the Bundesrat of the Kaiserreich was not a parliamentary body but rather a chamber representing the monarchical governments in the states. ${ }^{4}$ Indeed, sovereignty in the Reich resided in the Bundesrat. ${ }^{5}$

The distribution of seats in the Bundesrat was similar to that of the old imperial Bundestag. Prussia had 17 of 58 votes, more than the 14 needed 
to block constitutional amendments, and the members were instructed delegates sent by the state government to vote en bloc. But there was a crucial difference: the North German Federation of 1867 and the Kaiserreich of 1871 were federations with a central state, while the German Confederation of 1815 was a loose association of sovereign princes. ${ }^{6}$

Bismarck had thought originally of the Bundesrat as a potential government, or cabinet, which would counter the democratic pressures in the country as well as the fear that the Prussians would dominate the government. In fact the Bundesrat did not become either the basis of a cabinet or as strong a legislative body as the Reichstag, because the idea of the nation-state, which favored the Kaiser and the popularly elected Reichstag, was more powerful than the old-fashioned notion of a confederation of princes. ${ }^{7}$

The Constitution of the Kaiserreich thus held two principles of legitimacy in balance: the rising principle of democracy and the traditional principle of monarchy. On the other hand, the principle of government responsibility to parliament, as in Great Britain, was not yet established at the national or state level. The Bundesrat stood for the principle of federalism, but also for monarchy. Even though it was overshadowed by the Reichstag in the legislative process, it exercised veto power over the Reichstag and over constitutional change. It was, then, more than merely a chamber representing the states. ${ }^{8}$

\section{The Weimar Republic}

With the collapse of the Kaiserreich in 1918, a new Constitution, often seen as a model of democracy, was drafted and approved in a constitutional assembly in the quiet town of Weimar, southwest of and away from the then turbulent Berlin. The Weimar Constitution also provided for a federal system with eighteen, then seventeen, member states and a second chamber, now called the Reichsrat. Several different ideas concerning this body were discussed, but in the end it remained a chamber consisting of delegates selected by the governments of the states, ${ }^{9}$ now called Länder. Prussian dominance was broken by having the different provincial governments, rather than the central Prussian government, select delegates. A major difference to the past, of course, was that now the governments were democratically elected. The monarchies had been swept away in the wake of the lost war.

But the powers of the Reichsrat, in comparison with its predecessor, the Bundesrat, were reduced. It had no absolute veto, only a suspensive veto, 
the effect of which depended on the actions of the Reich President. It could not even stop constitutional changes. Like federalism in general, the Reichsrat proved to be a weak institution in a state that, confronted by a series of foreign and domestic crises, became more centralized and unitary than originally conceived. But the trend toward centralization was nothing in comparison to the Nazi dictatorship that overthrew the Weimar Republic in January 1933 and eliminated the Länder and dissolved the Reichsrat in 1934. ${ }^{10}$

\section{The new Länder after 1945 and the founding of the Federal Republic}

Between 1945 and 1949, when the Basic Law came into effect, eleven Länder emerged in the Western Allied zones of occupation, only four of which, Baden, Bavaria, and the city-states of Hamburg and Bremen, had existed before 1934. Prussia, half of which was annexed by Russia and Poland in 1945 and seen by the Allies as having been too large and its influence too militaristic (although this was not the case in the Weimar Republic), was dissolved altogether in 1946. The Americans re-established Bavaria and Bremen and created the Länder Hesse and Württemberg-Baden. The French created the Rhineland-Palatinate and Württemberg-Hohenzollern and considered annexing the Saarland until agreeing in the 1950s to return it to Germany. The British re-established Hamburg and created NorthRhine Westphalia, Lower Saxony, and Schleswig-Holstein as Länder. West Berlin remained an occupied city. Baden, Württemberg-Baden, and Württemberg-Hohenzollern were combined by the Germans - unlike the other new states - to form Baden-Württemberg in 1952. By this time, then, there were two large Länder in the North - North-Rhine Westphalia and Lower Saxony - and two large Länder in the South - Bavaria and Baden-Württemberg. Never before in German history had there been this kind of rough regional balance. In the East, the GDR had also created or revived five Länder after 1945, but they were virtually abolished in 1952 and replaced by fourteen districts in a highly centralized communist state.

In 1948 the Western Allies directed the Land governments to prepare a draft Constitution that, among other things, would have to provide for a federal system. ${ }^{11}$ Some Germans have argued or at least suspected that federalism after 1945 was imposed on them, ${ }^{12}$ but it is clear that the German constitutional founders also wanted a federal state. ${ }^{13}$ Federalism as such did not become a major issue in the Herrenchiemsee Conference that drafted the constitution; rather, it was the nature of the second chamber that created controversy. ${ }^{14}$ The SPD generally favored a more powerful 
elected parliament and a second chamber with reduced powers, while the $\mathrm{CDU}$ and CSU were more supportive of a second chamber equal in power to the parliament. The SPD and the CDU in the British Zone also favored a chamber comprised of uninstructed members selected by the Land parliaments, rather like the United States Senate before 1913, while the CSU and southwest German CDU preferred the German tradition of instructed members representing their governments, i.e., the old Bundesrat model. The FDP position was not clear. ${ }^{15}$

When the Herrenchiemsee Conference, a preparatory committee of experts, turned over its draft document in September 1948 to the Parliamentary Council - the official constitution-making body established by the Länder - it offered both the Senate and the Bundesrat solutions, the latter of which could be subdivided into "classic" and "weakened" alternatives. ${ }^{16}$ The Parliamentary Council finally reached a compromise favoring the "weakened" Bundesrat model. The Bundesrat was not given powers equal to those of the parliament, or Bundestag, as in the "classic" model, but the Constitution did grant membership on the basis of instructed delegates appointed by the Land governments. German federalists, after all, believed that the Länder should participate in law making and in the administration of federal laws, both of which were very much in the German tradition. ${ }^{17}$ This favored the representation of the Land governments in a second chamber of the Länder that would mediate between the federal and Land governments. This is the solution that is most federal, in the sense that it provides for a federal division of powers in which both levels are represented by governments. A Senate solution would have duplicated in the Bundesrat the party representation in the Bundestag, whereas representation in the Bundesrat was to be based on the different principles of continuity, stability (i.e., long-standing interests of the Länder) and administrative expertise. ${ }^{18}$ Thus the Bundesrat of the Federal Republic represents a special form of German federalism but not the old federalism of the German princes. ${ }^{19}$

\section{The Bundesrat today}

\section{Functions, composition, organization, and general procedures}

Even though Chapter IV (Articles 50-53) of the Basic Law is devoted to the Bundesrat, it focuses only on the basic function of the chamber, i.e., participation in the legislative process and administration of the federation 
and in matters affecting the EU; membership, representative principles and voting; rules of order, certain procedures and committees; and provisions concerning participation of federal cabinet members in Bundesrat proceedings. Many other key provisions concerning this body are found in other parts of the Basic Law. For example, details about the legislative process involving the federal government, Bundesrat, and Bundestag are contained in Articles 76 and 77; constitutional amendments, which require a two-thirds vote in each chamber, are discussed in Article 79; the Bundesrat's role in finance legislation is found in Articles 104a, 105-109, 134 , and 135; its role in approving federal regulations regarding the administration of federal laws by the Länder is outlined in Articles 84 and 85 ; its role in joint tasks is contained in Article 91a; the election by the Bundesrat of one-half of the judges of the Federal Constitutional Court is provided in Article 94; and other, generally less important, matters are found in a variety of other Articles. ${ }^{20}$

Together with the Bundestag, Federal Government, Federal President, and Federal Constitutional Court, the Bundesrat is a constitutional organ of the federation, but with a focus on federalism. It is a second chamber but not an "upper house" of parliament; nor is it a Länderkammer, or chamber of the Länder, in which the Länder deal with matters that affect them internally as regional units. Rather, Länderkammer, if that term is to be used, should be understood as a federal organ which allows the constituent parts of the union to participate in the governmental process of the whole state. ${ }^{21}$ This has led some observers to use the term "participatory federalism" in describing the German federal system.

Unlike the Bundestag which begins a new session after each federal election, the Bundesrat is a continuous body. Land governments decide if and when the members change, usually as the result of a change in the cabinet due to Land elections. The Bundesrat is not a body that represents the people directly, but rather one that represents elected Land governments. It is, therefore, in part an executive and in part a legislative body. ${ }^{22}$ The goal is not so much a democratic one as one that focuses on a German version of separation of powers and checks and balances. ${ }^{23}$ This, in turn, promotes use of the term, "administrative federalism" in Germany.

The Bundesrat is composed of members of and is appointed by the Land governments (cabinets). Only these cabinet members may vote in the plenary sessions; civil servants may participate in the regular committee meetings. The number of delegates each Land sends to the Bundesrat varies roughly according to population. Each Land has at least three votes. Länder with more than 2 million inhabitants have 4 
votes; with more than 6 million, 5 votes; and with more than 7 million, 6 votes (see table 10.1). Before unification the maximum number of votes for a Land was 5. In contrast to Prussia in the Kaiserreich, no one Land dominates the voting or has a veto over constitutional amendments. But while population is considered, the differences in size of population and territory between North-Rhine Westphalia or Bavaria on the one hand and Bremen or the Saarland on the other hand are dramatic. When the five new Länder were created in the former GDR, concern was expressed in the West that this would give the East, with a total of 16.4 million inhabitants, 15 votes and leave North-Rhine Westphalia, with 17 million inhabitants, 5 votes. To ensure that they would at least be able to block constitutional amendments that they might see as damaging their interests, in particular fiscal equalization among the Länder, the four large Länder in the West were given 6 votes each in the Unification Treaty of 1990 and in the amendment to the Basic Law of September 1990. In the Bundesrat tradition, the votes are cast as a block and on

Table 10.1 The German Länder: their populations, representation in the Bundesrat, and their capitals

\begin{tabular}{lrcl}
\hline State $($ Land $)$ & Population & $\begin{array}{c}\text { Seats in } \\
\text { Bundesrat }\end{array}$ & Capital city \\
\hline Baden-Württemberg & $10,300,000$ & 6 & Stuttgart \\
Bavaria & $11,900,000$ & 6 & Munich \\
Berlin $^{\text {a }}$ & $3,400,000$ & 4 & \\
Brandenburg $^{2,600,000}$ & 4 & Potsdam \\
Bremen $^{\text {a }}$ & 700,000 & 3 & \\
Hamburg $^{\text {a }}$ & $1,700,000$ & 3 & \\
Hesse $^{\text {Lower Saxony }}$ & $6,000,000$ & 5 & Wiesbaden \\
Mecklenburg-West Pomerania & $7,700,000$ & 6 & Hanover \\
North-Rhine Westphalia & $1,800,000$ & 3 & Schwerin \\
Rhineland-Palatinate & $17,800,000$ & 6 & Düsseldorf \\
Saarland & $3,900,000$ & 4 & Mainz \\
Saxony & $1,100,000$ & 3 & Saarbrücken \\
Saxony-Anhalt & $4,600,000$ & 4 & Dresden \\
Schleswig-Holstein & $2,800,000$ & 4 & Magdeburg \\
Thuringia & $2,700,000$ & 4 & Kiel \\
Federal Republic of Germany & $81,400,000$ & 69 & Berlin b \\
\hline
\end{tabular}

Notes: ${ }^{\text {a City-states; }}{ }^{\mathrm{b}}$ Berlin is now the official capital, but some ministries will remain in Bonn even after 2000 . 
instruction of the Land governments. In case the Land has a coalition government and the parties in the government do not agree on how to vote, the Bundesrat members from that Land will most likely abstain; this has the effect of a negative vote, since only positive votes are counted. All coalition governments sign detailed agreements before they form a government, and these include provisions concerning voting procedures in the Bundesrat. ${ }^{24}$ An obvious breakdown occurred in March 2002 when the delegation from Brandenburg was divided between the senior coalition partner, the SPD, and the junior partner, the CDU, over the vote for or against the SPD-Green government's immigration reform bill. In spite of a vote against cast by a CDU minister, the SPD prime minister, Manfred Stolpe, cast a vote in favor which provided the needed majority of 35 to 34 . Stolpe's vote was accepted as official by the then president of the Bundesrat, the SPD lord mayor of Berlin, Klaus Wowereit. ${ }^{25}$ Though this vote was considered to be unconstitutional by many experts, the president of the Federal Republic, Johannes Rau, reluctantly signed the bill which officially had passed the Bundestag and Bundesrat. That decision was then appealed to the Federal Constitutional Court, which ruled in autumn 2002 that the vote in the Bundesrat was, indeed, unconstitutional.

The Bundesrat elects a President each year on a rotating basis, beginning with the largest Land, North-Rhine Westphalia. The President is always a current Land prime minister or lord mayor of a city-state, and he is second only to the Federal President in terms of protocol. He calls and presides at the meetings of the Bundesrat, usually every third Friday, for a total of about twelve meetings per year. The meetings are public, but the public may be excluded under certain circumstances. Members of the federal government have the right to attend and speak at the plenary meetings as well as to participate in meetings of committees in which federal civil servants also may participate.

There is much less hierarchy in the Bundesrat than in the Bundestag. The prime ministers and ministers in the Bundesrat are formally equal, and the presidency changes every year. There is a certain hierarchy in the so-called "political committees" - foreign affairs and defense, in which the members are usually the Land prime ministers. The plenary meetings, which are prepared in advance and therefore generally dispose of the long agenda quickly and efficiently, are far more relaxed and business-like than in the Bundestag, and expressions of approval or disapproval from the listening members are very rare. ${ }^{26}$ 


\section{The Bundesrat and the legislative process}

The Bundesrat has the right to initiate legislation, but most bills come from the federal government (cabinet) or, to a lesser extent, from the Bundestag. ${ }^{27}$ In the most common case, the government sends its bill to the Bundesrat, which then has six weeks to respond. (If the bill is initiated by the Bundestag, that chamber deals with it first; if the bill emerges from the Bundesrat, it goes first to the federal cabinet and then to the Bundestag.) The President of the Bundesrat sends the bill directly to the relevant committees.

Most of the real work of the Bundesrat takes place in the committees, in which each Land is represented officially by the relevant Land cabinet minister. In the committee on foreign relations, the Länder are normally represented by the prime minister. Each Land has 1 seat and 1 vote in the committee, and majority votes there generally suggest how the Bundesrat will vote. However, since each Land, depending on its population, has from 3 to 6 votes in the plenary meetings, the majorities in the committee and later in the plenary meeting can be different. It is common for civil servants rather than for ministers to represent their Land in the committee, which, together with the pressures of time, explains why the bureaucratic influence in the Bundesrat is high. But having access to the expertise of Land bureaucrats in the legislative process that affects the Länder was one of the reasons for adopting the Bundesrat over the Senate alternative in the negotiations that led to the final version of the Basic Law. ${ }^{28}$

The committee must normally complete its work by Thursday, eight days before the next Friday plenary meeting of the Bundesrat before the end of the six weeks. The Land missions then begin a tightly organized process by informing their prime minister's staff (Staatskanzlei) of the committee's recommendation. The staff spends much of the week, and especially the weekend, discussing and coordinating views in the Land government. On Monday the chief of staff contacts his counterparts in other Länder with the same party majority to arrive at a common position. This means that the Land cabinets, which meet on Tuesdays, have only a few but well-prepared days to consider the legislation and to decide how to vote on Friday, when the Bundesrat meets. Thus the decisive stage for Bundesrat decisions is the cabinet meetings of the Land governments, but for ministerial coordination it is usually the committee stage. ${ }^{29}$

In effect the votes in the plenary meetings generally register the decisions taken in committees and, in case of disagreement there, in a special standing committee, the Permanent Advisory Committee, composed of 
the Land plenipotentiaries of the sixteen Länder, the Director of the Bundesrat, and a representative of the Federal Chancery. When the Bundesrat was still in Bonn, these meetings were held in "Room 13" of the Bundesrat building, and this tradition has been continued in Berlin. The Committee receives reports from the Federal Chancellor's Office regarding the meeting of the Federal Cabinet earlier in the afternoon. The members comment to the Federal "Reporter" from the perspective of their respective Länder, which provides a useful confidential communication link between the two levels. The meetings of the Committee are chaired by the oldest serving member, who also formulates statements if and when such are forthcoming.

For our purposes the more important functions of the Committee are the assistance it gives the President and Praesidium of the Bundesrat in preparing the plenary meetings and its advice regarding administrative tasks. Shortly before the plenary meeting of the Bundesrat the Committee meets again and, if it discovers that there are different views regarding the course or procedures of the upcoming meeting, the Committee, led by the Bundesrat President, attempts to reach a quick compromise regarding procedures or other disagreements. ${ }^{30}$

No later than the last Friday of the six weeks allowed the Bundesrat for action, that chamber votes on the bill. The votes for each Land are cast as a block, i.e., one member of the Land delegation casts from three to six votes. Normally no more than two members are present from any one Land, and sometimes only one member is present, since one member casts the votes for the Land. The results are then sent to the federal government which sends the bill to the Bundestag with its statement on any issues in dispute. After considering the bill in committee and possibly making certain changes with the approval of the government, the Bundestag either passes or rejects the bill. If the bill passes, it is sent to the Bundesrat a second time. The Bundesrat then has three weeks to react. The consequences of its actions depend on the kind of legislation being proposed (figure 10.1).

If it is a "simple bill" or "objection bill" (Einspruchsgesetz), i.e., one which does not involve the Länder in the bill's administration or finances, and the Bundesrat approves, it goes back to the government which gives it to the Federal President for his signature. If the Bundesrat does not approve, it can call for a meeting of the Mediation Committee, ${ }^{31}$ composed of one member from each Land and an equal number of Bundestag members, for a total of thirty-two. The number of members each party sends from the Bundestag is based on proportional representation. If the Mediation Committee reaches a compromise and first the Bundestag and 
then the Bundesrat accept, the bill goes to the government and the Federal President for his signature. If the Bundesrat does not accept the compromise, it has the right of a suspensive veto. If the veto represents a majority of the Bundesrat, i.e., at least 35 of 69 votes, it can be overridden by an absolute majority vote of the Bundestag. But if the suspensive veto represents a two-thirds majority of the Bundesrat, i.e., 46 votes, the Bundestag can override only by a two-thirds vote, which would be virtually impossible in all but the rarest of cases. Since the Opposition would rarely have a two-thirds majority in the Bundesrat, the government and its majority in the Bundestag can normally count on passage of their "objection bills."

If it is a "consent bill" (Zustimmungsgesetz) which is the case for about 55-60 percent of all bills (but about 90 percent of the more important bills ${ }^{32}$ ), the Bundesrat has potentially an absolute veto and is equal to the Bundestag in legislative power. This occurs when any part of the bill contains a provision concerning administrative procedures or certain issues of public finances, which are the province of the Länder. If the Bundesrat approves the bill, which it does in most cases, it goes back to the government which gives it to the Federal President for signing. If the Bundesrat does not approve, which is more likely to occur when the Opposition in the Bundestag has a majority in the Bundesrat, i.e., when there is "divided government," the Bundesrat, the federal government, or the Bundestag can each call one time for a meeting of the Mediation Committee. If the Mediation Committee is unable to reach any compromise agreement, the bill is dead. If it does reach a compromise, the bill goes back to the Bundestag, which must vote the compromise up or down without amendment. If accepted, the bill goes back to the Bundesrat for its consent. Whether an objection bill or a consent bill is involved, the Bundesrat has three weeks to respond to the Bundestag in its "second reading." In the case of a constitutional amendment, the Bundesrat also has an absolute veto in that both the Bundestag and the Bundesrat must approve the amendment by a two-thirds vote. ${ }^{33}$

If one looks at the statistics from 1949 to 1994, one sees that the federal government, which initiates about 60 percent of all legislation, has a success rate of final passage of about 86 percent. The Bundestag, with about 33 percent of the initiatives, has a success rate of about 33 percent, and the Bundesrat, with less than 10 percent of the initiatives, also has a success rate of about 33 percent. Surprisingly, the Bundesrat has approved 98 percent of the bills sent to it after approval by the Bundestag. ${ }^{34}$ Thus, it tends either to approve legislation sent to it or to accept compromises in the Mediation Committee when it disagrees. 


\section{"Consent bill" (Zustimmungsgesetz)}

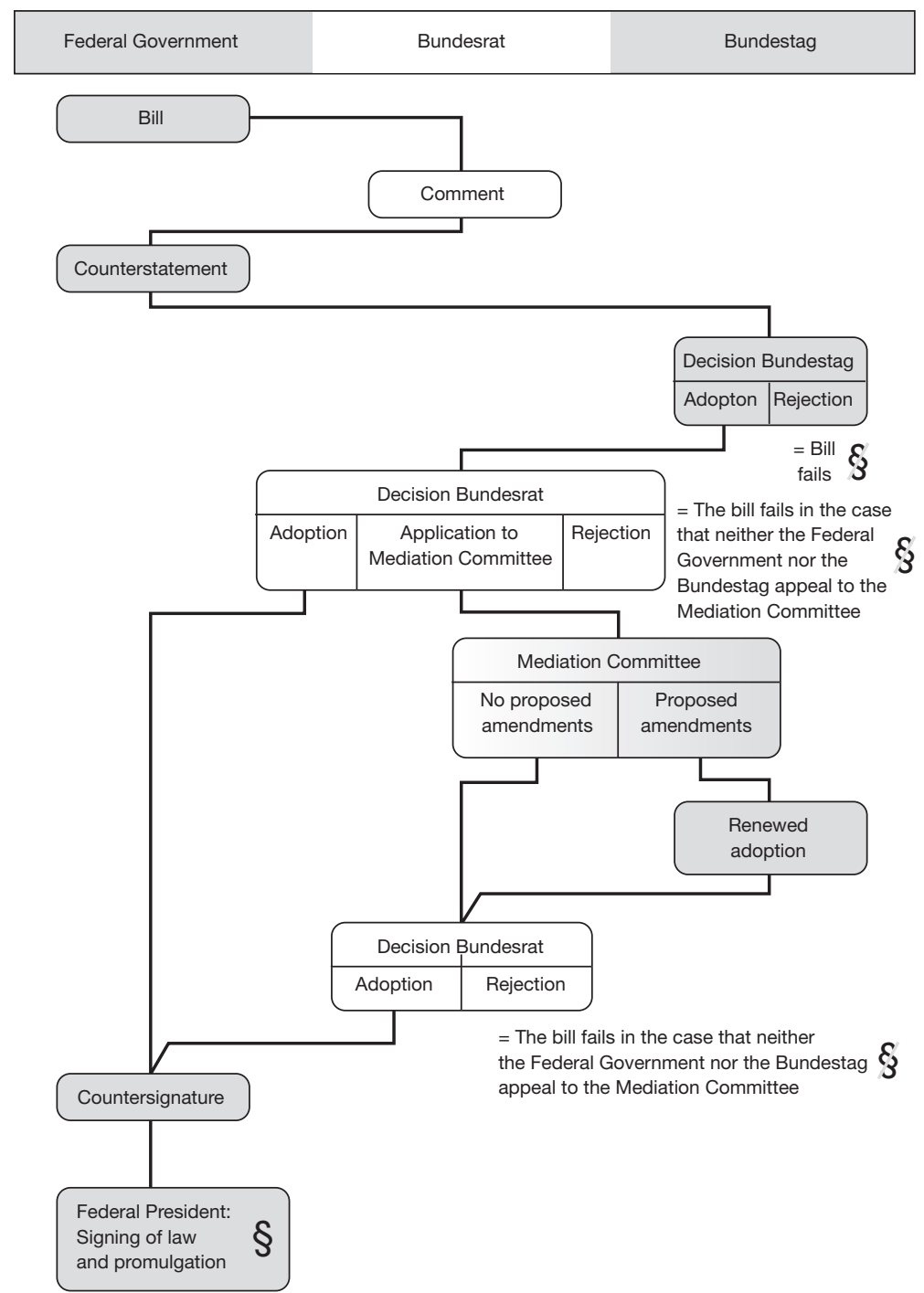

Figure 10.1 The legislative process and the Bundesrat

Source: Deutscher Bundesrat. 


\section{"Simple" or "objection" bill (Einspruchsgesetz)}

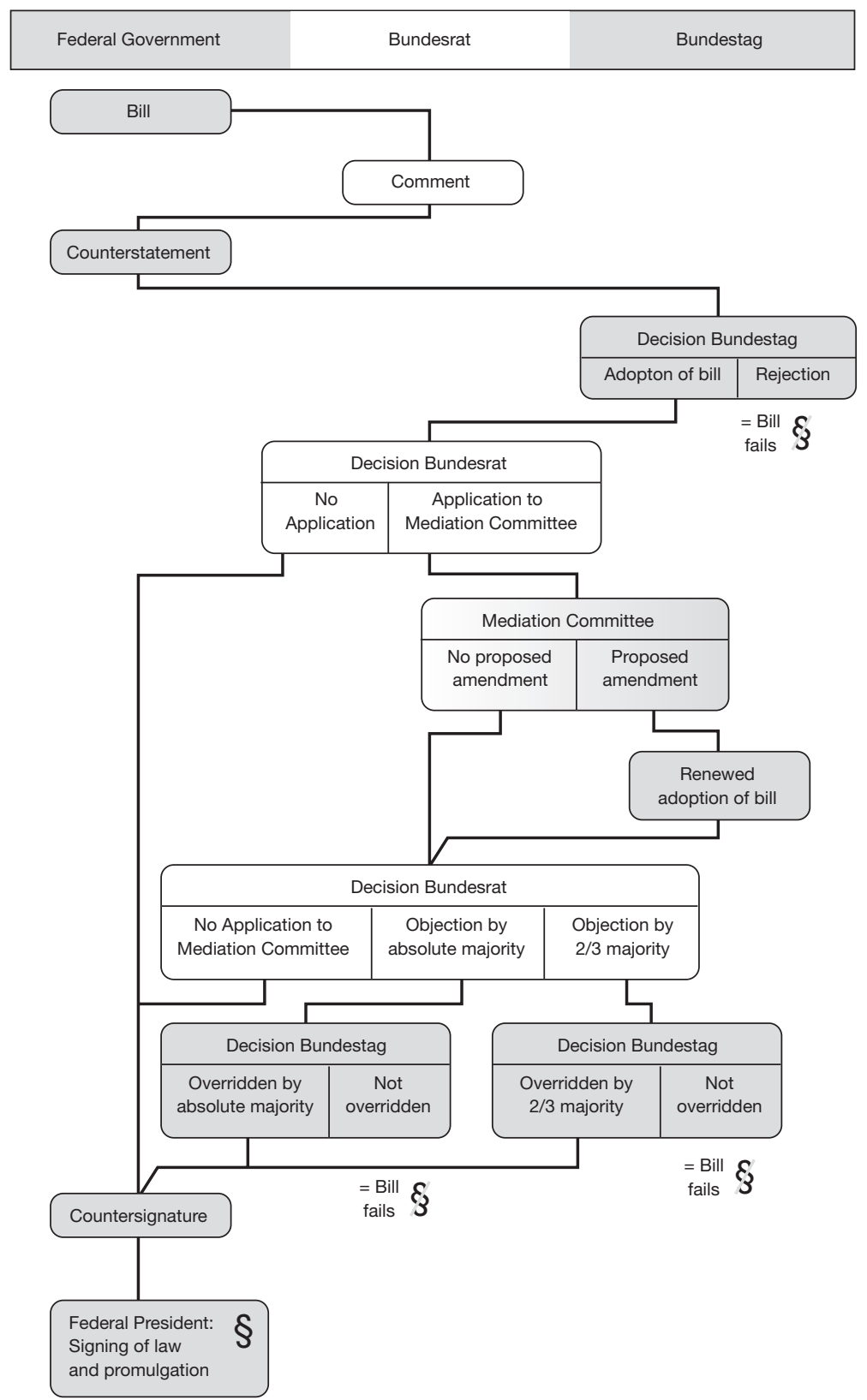


This does not mean, however, that the Bundesrat in practice has little power. In the first place, it is involved in the legislative process from beginning to end, except for bills initiated by the Bundestag, with many opportunities to exercise varying degrees of influence. In the second place, most deliberations in the Mediation Committee end in compromise acceptable to both the Bundestag and the Bundesrat and, of course, the federal government. In the third place, when the Bundesrat rejects a bill and any attempts to reach a compromise in the Mediation Committee, it is virtually by definition an important piece of legislation, whether it is an objection bill or a consent bill.

The range in the percentage of consent bills vetoed in four-year periods from 1949 to 1998 was $0-5.7$. The most contentious periods were from 1972 to 1983 and from 1990 to 1998, when the Opposition (in the 1970s the CDU/CSU, in the 1990s the SPD) had a majority in the Bundesrat and was accused of a politics of "blockade" vis-à-vis the government. Even though a number of important government bills were, indeed, blocked by the SPD and their Green allies in the divided government of the 1990s (twenty-one each in the period 1990-94 and 1994-98), the percentage of all consent bills vetoed was only 2.6 and 2.3 , respectively. ${ }^{35}$

The Bundesrat can call for a meeting of the Mediation Committee within three weeks of the receipt of a bill passed by the Bundestag. (Or, in the case of a consent bill, it can reject the bill outright, p. 350.) In contrast to the plenary meetings, the sixteen members from the Bundesrat in the Mediation Committee are not bound by instructions from their governments, and members from the Bundestag are also free to vote with their consciences under Article 38 of the Basic Law. Needless to say, given the strong party discipline in Germany, one can be skeptical about just how "free" members from either organ really are, and some see the Bundesrat as a crucial location for party politics. ${ }^{36}$ Nevertheless, on certain occasions the Länder do break party ranks because of competing Land interests. ${ }^{37}$ Some observers even suggest that party politics has had a real impact in only a minority of cases overall, even though party interests become more important in conditions of divided government..$^{38}$

Members of the Mediation Committee may not bring any civil servant experts with them; only "genuine" members, i.e., Land ministers and Bundestag members may participate. The Committee is seen as an instrument of political compromise and consensus, and its meetings are confidential and not open to the public. Minutes are published only after an intervening session of the Bundestag, i.e., at the earliest about five years after the meeting took place. Members are not legally required to report 
back to their respective bodies, and the compromise proposals that emerge from the Mediation Committee must normally be accepted or rejected by the Bundestag and Bundesrat without change. ${ }^{39}$

As indicated in the analysis above, the Mediation Committee is a powerful and, therefore, somewhat controversial body. It combines the principles of territorial and political representation and serves as a balance between democratic and federal elements. But the fact that its meetings are closed to the public, that reporting back to the two chambers is not required, and that the Committee's compromise proposals are not normally subject to amendments are viewed by some critics as having the combined effect of reducing the legislative powers of the democratically legitimated Bundestag. On the other hand, these procedures are also seen as the conditions for promoting compromise. ${ }^{40}$ The Mediation Committee becomes especially controversial when, as in the 1970s up to 1982 and during the 1990s, the Opposition in the Bundestag has a majority in the Bundesrat and the Mediation Committee is used sometimes as an instrument of opposition.$^{41}$ In such cases it is especially clear that the Bundesrat is not just a constitutional organ; it is also a political instrument. ${ }^{42}$

This development is a result in part of the proportion of bills that are consent bills, i.e., bills over which the Bundesrat has an absolute veto. As indicated above, the proportion of consent bills has been about 55-60 percent for several decades. In the very first session of the Bundestag from 1949 to 1953, the proportion of 43 percent was higher than expected. While this could be seen as a positive development for German federalism, it can also be interpreted negatively. Constitutional experts have noted that consent by the Bundesrat is now required for many bills because their legislative content was given to the federal government by constitutional changes that, in fact, were made at the expense of the Land parliaments. This is especially the case in concurrent legislation. Thus, there has been an increase in federal laws that are administered with considerable uniformity by the Länder and therefore require Bundesrat consent. On the other hand, the increase in consent laws has given the Bundesrat more influence over the contents of federal legislation, not just their administrative features, which then can lead to controversy over whether the Bundesrat can reject a government bill on the grounds of its contents rather than because of administrative procedures, as was the intent of the constitutional founders. The Bundesrat is not obliged to give reasons for its rejection of a bill. This has led to the federal government's attempts on occasion to divide bills into multiple parts in order to avoid as much as possible rejection of the whole package in the Bundesrat. ${ }^{43}$ 
It is often argued that while the federal government has gained legislative powers since 1949, especially in the area of concurrent legislation, the Länder have been compensated by their rights of administration and the increase in the proportion of consent laws. As we have seen above, however, it is the Land governments, not the Land parliaments, that have been compensated. It is generally agreed that the Land parliaments have been the net losers in the federal legislative process and in the transfer of general Land legislative powers to the federal government. This is a major reason why some observers refer to German federalism as "executive federalism." ${ }^{44}$

\section{Territorial vs partisan politics in the Bundesrat}

As noted above, there were two periods in the 1970s and 1990s in particular, when strong criticism of the Bundesrat arose because of the "gridlock" between the government and its majority in the Bundestag and the majority of Länder votes in the Bundesrat. This criticism is based not only on the traditional view that the Bundesrat has the function of territorial representation, while the Bundestag has the function of partisan political representation, but also on the more modern argument that a politics of "blockage" in the Bundesrat undermines the political responsibility or accountability of the popularly elected Bundestag. This is the main thesis of Gerhard Lehmbruch, cited in Chapter 9, who pointed to the bargaining and cooperation required by Politikverflechtung in general and in the Bundesrat in particular and the kind of hidden grand coalition or all-party politics that resulted. But the partisan disagreements that were perceived in the 1990s appeared to go beyond a kind of all-party government to "gridlock" between the two legislative bodies and the parties that controlled them. There was strong public criticism of the Bundesrat, especially in the electoral period between 1994 and 1998, because it appeared that some of the Kohl government's badly needed economic reforms were being blocked as a result of opposition by the Social Democrats and Greens who together had won enough elections in the Länder to gain a majority of votes in the Bundesrat. But while the general public and many scholars complained about "gridlock" or at least noted the questionable role of partisan politics in the Bundesrat, some scholars argued that the failures to agree were exaggerated and, in the case of the important tax reform proposal, not so much the fault of the Opposition as that of the smaller coalition parties, FDP and $\mathrm{CSU}^{45}$ (a view strongly contested by others). ${ }^{46}$ Two non-German scholars even suggested that in fact territorial politics were increasingly replacing the more partisan relationships in the Bundesra $t^{47}$ or 
that disagreements between the Bundestag and Bundesrat are a natural result of different electoral outcomes at the federal and Land levels and should therefore be considered part of the normal political process. ${ }^{48}$

\section{The Land missions in Berlin ${ }^{49}$}

All of the Länder have missions in Berlin headed by an official Land representative who serves as a kind of Land ambassador, lobbyist, liaison officer, and spokesperson for the Land government. The Land representative normally divides his or her time between Berlin and the home capital. A number of high-level civil servants are also assigned to the mission. They normally staff the Bundesrat committees for their Land and assist in liaison functions between Land and federal ministers and among civil servants of other missions, especially with regard to Bundesrat matters. The missions also are informed by the federal government of issues affecting the Länder.

In order to be able to report back to their governments, the civil servants in the missions have the right to attend all Bundestag plenary meetings and committee meetings, with the right to be heard in the latter. In plenary sessions this right is reserved in practice for Land prime ministers or subject ministers (department heads). Attendance of Bundestag committee meetings by Land civil servants is important so that they can report back immediately to their governments; this is essential in order that the Länder can react to Bundestag actions within the generally limited time they have at their disposal.

In addition to the above functions, the Land missions serve as a place where the Land delegation in the Bundestag can meet, regardless of party affiliation. The missions also perform public relations tasks, such as providing information and organizing cultural events, lectures, and various social gatherings. They serve as places for interest groups from the Land to meet with members of the Land delegation in the Bundestag or federal ministers. From this brief description, it is understandable that the Land missions have been called the "spiders in the web" 50 of relationships between the Länder and the federal government.

\section{Conclusion}

For several centuries the states were represented, first, in the Holy Roman Empire, by a Reichstag, then in the German Confederation by a Bundestag, 
and in the North German Federation and the Bismarck Reich by a Bundesrat. During the Weimar Republic of 1919-33, the states were represented by a Reichsrat, and since the emergence of the Federal Republic in 1949 the Bundesrat has made its reappearance. It is clear, then, that in spite of the numerous changes of regime, composition, and functions, the current Bundesrat has deep roots in German history.

Its historical function was to create some degree of union from many separate states and in the process secure the autonomy of the individual parts from the central authority. But this is no longer true in the Federal Republic. The legitimacy of the federal state in Germany today is based on constitutional postulates: democracy, rule of law, the welfare state, and federalism. Federalism today serves as an additional means of dividing power and thus of encouraging liberty. ${ }^{51}$

The Bundesrat today is very different in some key respects from its predecessors. It shares the function of representing the constituent parts of Germany before the central authority and of participating in the decision making process of that central authority. Its decision making powers are especially important in legislation that deals with the administrative responsibilities of the Länder. But with the exception of the short-lived Weimar Republic, it differs sharply from the past in that it consists of representatives of democratically elected Land governments. It is not dominated by any single state or a combination of a few large states, and it serves both as an important check on the federal government and Bundestag as well as a joint decision maker on a majority of laws. For all of these reasons German federalism is sometimes referred to as "participatory," "administrative," or "executive federalism." In any case, the Bundesrat, next to the United States Senate, is arguably the most important second chamber in any other democracy, let alone any other federation.

\section{Notes}

1 Hans-Georg Wehling, "The Bundesrat," Publius: The Journal of Federalism 19, no. 4 (Autumn 1989), p. 53.

2 Peter Graf Kielmansegg, "Vom Bundestag zum Bundesrat: Die Länderkammer in der jüngsten deutschen Verfassungsgeschichte," in Vierzig Jahre Bundesrat, edited by the Bundesrat (Baden-Baden: Nomos Verlagsgesellschaft, 1989), p. 43.

3 Wehling, "The Bundesrat," p. 56.

4 Kielmansegg, "Vom Bundestag zum Bundesrat," pp. 44-45.

5 Uwe Thaysen, "The Bundesrat, the Länder and German Federalism," German 
Issues 13 (Washington, DC: American Institute for Contemporary German Studies, 1993), p. 5.

6 Kielmansegg, "Vom Bundestag zum Bundesrat," pp. 46-47.

7 Ibid., pp. 48-49; Thaysen, “The Bundesrat," pp. 5-6.

8 Ibid., p. 50.

9 Ibid., pp. 52-53.

10 Thaysen, "The Bundesrat," pp. 6-7.

11 For an excellent study of the developments leading to the Allied decisions regarding the drafting of a German Constitution, see John Ford Golay, The Founding of the Federal Republic of Germany (Chicago: University of Chicago Press, 1958), Ch. 1.

12 Kai-Uwe von Hassel, "Der Bundesrat zwischen Länderinteressen, gesamtstaatlicher Verantwortung und Parteipolitik," in Bundesrat, Vierzig Jahre Bundesrat, p. 72.

13 Thaysen, "The Bundesrat," p. 12.

14 Heiderose Kilper and Roland Lhotta, Föderalismus in der Bundesrepublik Deutschland: Eine Einführung (Opladen: Leske \& Budrich, 1996), pp. 93-95.

15 Kielmansegg, "Vom Bundestag zum Bundesrat," pp. 53-54.

16 Thaysen, "The Bundesrat," pp. 12-13; Golay, The Founding, p. 41.

17 Wehling, “The Bundesrat," p. 55.

18 Kilper and Lhotta, Föderalismus, p. 94.

19 Kielmansegg, "Vom Bundestag zum Bundesrat," pp. 55-60.

20 For a table containing the locations of provisions throughout the Basic Law that relate to the Bundesrat, see Kilper and Lhotta, Föderalismus, p. 113.

21 Ibid., pp. 114-115. See also Heinz Laufer and Ursula Münch, Das föderative System der Bundesrepublik Deutschland (Bonn: Bundeszentrale für politische Bildung, 1997), pp. 111-112.

22 Peter Lerche, "Principles of German Federalism," in Germany and Its Basic Law, edited by Paul Kirchhof and Donald P. Kommers (Baden-Baden: Nomos Verlagsgesellschaft, 1993), pp. 71-90. A German language edition of this book is also available under the title, Deutschland und sein Grundgesetz.

23 Karlheinz Neunreither, "Politics and Bureaucracy in the West German Bundesrat," American Political Science Review 53, no. 3 (September 1959), pp. 713 and 723; Kilper and Lhotta, Föderalismus, p. 115.

24 Thaysen, "The Bundesrat," p. 28.

25 See several articles in Das Parlament 13-14 (2-5 April 2002), p. 3.

26 Helmut Herles, "Der Stil von Bundesrat und Bundestag: Kammerton und Schaubühne," in Bundesrat, Vierzig Jahre Bundesrat, pp. 231-250.

27 For a discussion by the previous director of the Bundesrat's legislative initiatives, see Georg-Berndt Oschatz and Horst Risse, "Bemerkungen zum Gesetzesinitiativrecht des Bundesrates," Zeitschrift für Gesetzgebung 4, no. 4 (1989), pp. 316-331.

28 Kilper and Lhotta, Föderalismus, pp. 120-121. 
29 Interview with a former Bundesrat member.

30 Peter M. Schmidhuber, “Zimmer 13,” Miterlebt-Mitgestaltet: Der Bundesrat im Rückblick, edited by Rudolf Hrbek (Stuttgart: Bonn Aktuell, 1989), pp. 266-270; Laufer and Münch, Das föderative System, pp. 118-119.

31 For a detailed discussion of the Mediation Committee, see Diether Posser, "Der Vermittlungsausschuß," in Bundesrat, Vierzig Jahre Bundesrat, pp. 203211.

32 Kilper and Lhotta, Föderalismus, p. 175.

33 For a detailed description of the legislatve process and the Bundesrat, see Kilper and Lhotta, Föderalismus, pp. 122-126.

34 Ibid., pp. 125-126.

35 Roland Sturm, Föderalismus in Deutschland (Berlin: Landeszentrale für politische Bildungsarbeit, 2001), pp. 62-63.

36 Uwe Leonardy, "Parteien im Föderalismus der Bundesrepublik Deutschland: Scharniere zwischen Staat und Politik," Zeitschrift für Parlamentsfragen 33, no. 1 (March 2002), pp. 183-185; Thaysen, “The Bundesrat,” pp. 25-27.

37 Posser, “Der Vermittlungsausschuß," p. 208. There are some dramatic examples of the national parties being ignored by the Land parties. One was in 1992 when the refusal of the SPD Land government of Brandenburg to back the national SPD led to the passage of the CDU/CSU-FDP government bill to raise the VAT from 14 to 15 percent and thus increase funds going to the Länder. The most recent example concerns tax reform legislation of the SPD-Green government which passed the Bundesrat in July 2000 because the CDU, which was a grand coalition partner in three Länder, and the FDP, which was a minority coalition partner in one Land, agreed to support a compromise solution which was, at least in the case of the CDU, against the wishes of the national party leaders.

38 Wehling, “The Bundesrat," p. 59.

39 Kilper and Lhotta, Föderalismus, pp. 127-128.

40 Posser, "Der Vermittlungsausschuß," p. 206; Thaysen, “The Bundesrat," p. 21.

41 Kilper and Lhotta, Föderalismus, pp. 126, 128-129.

42 Friedrich Vogel, "Der Vermittlungsausschuß," in Bundesrat, Vierzig Jahre Bundesrat, pp. 213-214.

43 Peter Lerche, "Zustimmungsgesetze," in Bundesrat, Vierzig Jahre Bundesrat, pp. 185-189, 196.

44 See, for example, Wilhelm Hennis, "Am Föderalismus liegt es nicht: Aber der Bundesrat hat sich als kapitale Fehlkonstruktion erwiesen," Frankfurter Allgemeine Zeitung (14 August 1997), p. 31. "Executive federalism" is not a new term; nor is it the only term that focuses on the role of the executive in German federalism. See, for example, Peter Merkl, "Executive-Legislative Federalism in West Germany," American Political Science Review 53, no. 3 (September 1959), pp. 732-741, in which Merkl contrasts German executive-legislative federalism to the US model of "mutual-independence" or dual federalism. 
45 Wolfgand Renzsch, "Die grosse Steuerreform 1998/99: Kein Strukturbruch, sondern Koalitionspartner as Vetospieler und Parteien als Mehrebenensysteme," Zeitschrift für Parlamentsfragen 31, no. 1 (March 2000), pp. 187-191.

46 Raimut Zohlnhöfer, "Der Parteienwettbewerb, die kleinen Koaltionspartner und das Scheitern der Steuerreform. Eine Erwiderung auf Wolfgang Renzsch,” Zeitschrift für Parlamentsfragen 31, no. 3 (September 2000), pp. 719-724.

47 Charlie Jeffery, "Party Politics and Territorial Representation in the Federal Republic of Germany," West European Politics 22, no. 2 (April 1999), pp. 159-161; for a somewhat similar view, see Roland Sturm, "Party Competition and the Federal System: The Lehmbruch Hypothesis Revisited," in Recasting German Federalism, edited by Charlie Jeffery (London and New York: Pinter, 1999), pp. 197-216.

48 Stephen J. Silvia, "Reform Gridlock and the Role of the Bundesrat in German Politics," West European Politics 22 (April 1999), pp. 167-181.

49 This section is based on Uwe Leonardy, "The Working Relationships between Bund and Länder in the Federal Republic of Germany," in German Federalism Today, edited by Charlie Jeffery and Peter Savigeau (London: Leicester University Press, 1991), pp. 48-50.

50 Ibid.

51 Alfred Kubel, “Bewährungen und Versäumnisse im Bundesstaat," in Hrbek, Miterlebt-Mitgestaltet, pp. 50-51. 